\title{
War, peace, and development
}

\section{J. Paul Dunne}

J. Paul Dunne is Professor of Economics, Department of Economics, University of Cape Town, Cape Town, South Africa.. He can be reached at john.dunne@uct.ac.za.

\section{Abstract}

Historically, peace and security have been important issues in economics. Yet for contemporary economics, issues of peace and security are marginal, and economists are conspicuous by their absence in debates to a degree that rivals the importance of the problems. Strikingly, economics textbooks in general, and development economics textbooks in particular, seldom give consideration to violent conflicts despite the dreadful impact they have on populations in the very poorest of countries. Similarly, they seldom deal with issues of peace and post-war reconstruction despite their importance for successful development. This article reviews some achievements within the economics of peace and security field and considers how our understanding of the preparation for violent conflict and the determinants and costs of conflict has been improved by research and what this might entail for some of the challenges ahead. In particular, the article identifies the challenge of constructing a peace economics that will allow for the design of economic systems that embed peace and overcome many of the conditions that continue to maintain the prevalence of violent conflict around the world.

$\mathrm{H}$ istorically, peace and security have been important issues, both in economics and in other scholarly disciplines. For example, scholars of international relations debate mercantilist perspectives-where economic benefits arise through conflict and control, making war inherent in interstate relations, and peace is an unusual state requiring a hegemonic power to maintain it - and contrast it with both, the liberal belief that war is an aberration, as free trade and free markets create wealth and war damages these relations, and a Marxist position that focuses on economic power. Add in realist arguments, according to which countries act in their self-interest and conflict is an extension of politics, and oppose that to idealist arguments that nation-states can act selflessly as reflected in international bodies such as the United Nations. Positions such as these generate continued debate. ${ }^{1}$

Yet for contemporary economics, issues of peace and security are marginal, and in the relevant scholarly and policy debates economists are conspicuous by their absence to a degree that rivals the importance of the problems. Strikingly, economics textbooks in general - and development economics textbooks in particular - hardly mention peace and seldom give consideration to violent conflict, despite the dreadful impact it can have, both on populations in the very poorest of countries and on the importance of maintaining property rights to allow markets to work. This is odd as considerable economics research has made important contributions to understanding security but often this has not been tied together or influenced mainstream economics and policy. ${ }^{2}$

One important failure concerns the lack of integration of the international relations and political economy theoretical perspectives to economics. True, some overlap exists. Political scientists and economists debate and cross-publishing occurs: Economists publish in political scientist's journals and vice versa. But the more foundational theoretical discussion remains outside the domain of economics discourse. Partial equilibrium analyses dominate and there is little recognition that security issues are fundamental to market economies. Indeed, want of security presents considerable challenges to their existence and efficient functioning. This lack of comprehension and integration is unfortunate as it means that when economists provide policy advice regarding conflict and post-war environments it is almost inevitably wrong. In some influential cases, it is even ignorant of the limited work that has done in peace and security economics itself. ${ }^{3}$

Some effort has been made to elevate the field, with limited success. This includes associations such as Economists Against the Arms Race (ECAAR), now called Economists for Peace and Security (EPS), which help provide professional profile and an important network. Publishing in the scholarly journals Defence and Peace Economics, Peace Science, Peace Economics and Public Policy, and The Economics of Peace and Security Journal, and economists publishing in other outlets, e.g., in the Journal of Conflict Resolution and Journal of Peace Research as well as over 20 years of the Europeanbased International Conference on Economics and Security, show coverage of a growing range of topics. Every now and again a topic will fire the imagination of the general economics profession and some nonspecialist economists will "parachute" 
in, at times in ignorance of the extant literature. But the field, such as it is, remains a subarea in economics.

Yet peace and security are central, not marginal. Resources devoted to the military sector are historically high. The Stockholm International Peace Research Institute (SIPRI) estimates world military expenditure at USD1.8 trillion in 2014, or around 2.3 percent of world GDP. Given reporting and categorization issues, this is a lower bound estimate. (As a rule, veterans' care and homeland security, for example, are not included.) Measured as it is, the United States accounts for around 40 percent of world military expenditure. Following the second world war a brief period of disarmament commenced. It quickly ended when the outbreak of the Korean war led to a big hike in world military expenditure, never to come down to their 1950s level again. Thawing cold war enmities in the mid-1980s markedly reduced military spending - and halved the value of the global arms trade in major conventional weaponry by the mid-1990s - but post-2001 (i.e., post-9/11) such spending increased again. The world financial crisis of 2008 arrested military expenditure - in fact, it declined in absolute, real terms - but as a share of GDP it remains, today, very high by historical standards. Beyond spending, even low estimates suggest that civil war-the most prevalent form of war today - reduces GDP growth by an average of two to three percentage points per war year and, as contemporary Syria shows, such wars can last for extended periods of time. In addition, they have damaging effects on neighboring states so that the total cost of war can be four times the cost to the country in which it takes place. All this is very concerning given that most wars take place in the poorest countries. ${ }^{4}$

This essay reviews the developments in the field, briefly and of necessity selectively. It identifies achievements but also failures and future challenges. It considers, first, what has been learned about the preparation for war, which comprises the dynamics and effects of military spending, the arms industry, and the global arms trade; second, the causes and consequences of violent conflict; and, third, the economics of post-war reconstruction. In the process, it emphasizes the need to develop a field of peace economics, separate from war or conflict economics. This journal has been championing peace and security economics so it is not surprising that this essay references many of the journal's pieces. By design they provide useful summaries and a range of further readings for the interested scholar, policymaker, and the general public.

\section{Preparation for violent conflict}

\section{Military expenditure}

Characterized by a belief that peace equals the absence of war, much of the focus of research has been on the provision of
Even as violent conflict remains central to human affairs, the economics discipline treats the subject matter of peace and security in a marginal way. This article identifies achievements the field of peace and security economics has made, but also failures and future challenges. It considers, first, what has been learned about the preparation for violent conflict, which comprises the dynamics and effects of military expenditure, the arms industry, and the global arms trade; second, the causes and consequences of violent conflict; and, third, the economics of post-war reconstruction and peace. The article emphasizes the need to more fully develop the emerging field of peace economics as separate from-or at least markedly distinct from-war and conflict economics.

security and the preparation for war. In this vein, developing an understanding of the determinants and effects of military expenditure is important. A number of achievements can be recounted. Unsurprisingly, empirical work confirms that the security environment, especially external shocks, threats, and most obviously wars, go some way to explain changes in military spending. But the spending level or spending burden (the share of military spending in GDP) are not just linked to security considerations. Important economic and political drivers have to be taken into account as well. While the perceived security environment helps determine the objectives to be met, budget constraints do influence the level and growth of military expenditure, whatever the security situation. This will not surprise economists but needed to be established empirically to convince researchers from other subject areas as well as commentators and policymakers. Other factors that influence the levels and growth of world military spending include cold war-era inertial effects (e.g., in regard to the nature of weapons systems), the nature and entrenched structure of decisionmaking organs, and decisionmaker precepts and attitudes. Thus, former army general and U.S. President Eisenhower famously warned against the influence of a Military Industrial Complex, highlighting its vested interests, pork-barrel politics, revolving door employment, political deals, and the pushing of military solutions to diplomatic problems. To this day, indeed, spurious arguments continue to surface regarding the supposedly economically beneficial nature and importance of military spending to national economies. ${ }^{5}$

Debate over the economic effects of military expenditure continues but a consensus finding is emerging due to the most recent studies, which include long data series spanning both the cold war and post-cold war eras. The information increase in the datasets (a better signal-to-noise ratio) makes it easier than before to identify causal relationships, if any, from military expenditure to economic growth. Findings thus have moved 
from generally negative but often statistically insignificant to generally negative and usually statistically significant effects. This does not mean that military spending can never result in positive short-run economic effects for particular countries at particular times (a simple Keynesian multiplier will increase short-run growth). But the long-run effects tend to be negative, and this does suggest that policy should justify military expenditure by security concerns, not economic reason. ${ }^{6}$

\section{The global arms industry and arms trade}

Recognition of the role that the Military Industrial Complex can play in determining levels of military expenditure is linked to important research on the nature, structure, and development of the global arms industry and its associated trade. Without understanding its cold war origins, and its vested interests, it is not possible to understand the arms industry as it exists today. ${ }^{7}$

Careful research has built up a clear picture of the cold war origin of today's industry, with its move away from civilianoriented products and services and its particular state-oriented characteristics and links toward structural changes that feature internationalization, increased links to the civilian sector, and changing technologies. Importantly, it has become clear that relative to the non-arms industrial sector the arms industry is not all that important to the domestic economies of the producing states. For most states, an arms industry can be justified in terms of national security strategy only, not in economic terms. But because of the far-reaching tentacles of its vested interests, new concerns about the changing nature and visibility of this sector have arisen. Increasingly, the industry takes over what once were activities of the armed forces. One consequence is that the private sector is increasingly involved in violent conflict, making skewed incentives and transparency growing concerns as well: Rather than profiting just from producing and supplying arms, companies are directly profiting from violent conflict itself. In particular, incentives are created to push military solutions to problems, both those directly linked to security threats and those not. ${ }^{8}$

Justifications in favor of domestic arms industries continue to be made, for instance, as providing innovations to the civilian, non-arms sector. But statements are not arguments and evidence. Those who argue these benefits should show they would not, and could not, have arisen otherwise. Evidence is generally absent. The justifications also ignore that the nature of the companies has changed. No longer massive production companies, they are dominated today by $R \& D$ and systems integration with considerable subcontracting and development of international supply chains. Civilian-led technology dominates in a number of seemingly military areas to such an extent that "commercial off the shelf" product use is now routine. Indeed, to gain civilian-inspired new technological expertise, military contractors purchase and take over civilian contractors, a far cry from the still prevailing image of dominant arms companies spinning off technologies beneficial to the non-arms sector. This false image also ignores findings of the conversion literature. This showed how difficult it is to move from military to civilian economic activity as the anachronistic development of military technology, production, and market structure during the cold war period had led to a marked divergence of civilian and military technology, production, and marketing and made it difficult to move from one to the other. ${ }^{9}$

The continued belief that military industries are particularly important to economies is rendered impotent simply because they do not represent particularly large parts of production or trade in most countries. As a means of justifying continued high spending, arguments that military industry is good for the economy at large resurface every now and again, but research has shown that this is at best debatable and at worst a myth. ${ }^{10}$

Understanding the changing nature of the industry also allows us to understand better the dynamics of the global arms trade and the prevalence of corruption in it. Countries still wish to maintain domestic defense industry capability, of course, and, certainly since the end of the cold war, at lowest possible cost. The dominance of the United States and the size of its armed forces mean that weapons systems will receive orders far beyond what any other country's domestic arms industry could garner. Such are the economies of scale and scope that they lead to unassailably low unit costs. Even as other countries produce weapons for the export market to reduce unit costs, still they cannot compete with the United States on price and so have to use other means. This has led to direct and indirect subsidies and arms trade offset policies that hide corruption in the trade. Commissions and bribes now make up a large component of arms deals. ${ }^{11}$

For the duration of the cold war years a clear ideological bias to research on the arms industry and trade could be seen, and in some ways this seems to be returning. But there has also been a marked change in the focus of the industry itself, exemplified by a rapid shift to information technologies, the use of unmanned aircraft (drones), and electronic (cyber) conflict. All of these are further undermining the traditional focus on large integrated, platform-based weapons systems that dominated the industry in the past.

In this field of research - military expenditure and the arms industry - concerns over data remain. Incompletely measured as it is, military spending captures budget inputs not security outputs. Just what does a military dollar buy? And regarding the industry, while some data is available through the SIPRI 
database and is of value, a number of issues have to be dealt with. As the industry restructures, it becomes increasingly difficult to compare data over time. The composition of the firms involved has changed. This, in turn, affects their behavior and carries policy implications which differ from those of the past. Even as the Military Industrial Complex per se is maintained, these changes in composition and character make the industry look rather different and make continued analysis a major challenge. ${ }^{12}$

\section{Causes and consequences of violent conflict}

As discussed, although a recent major review in the Journal of Economic Literature takes an economic perspective on an influential international relations textbook, the analysis of interstate conflict has mainly been the domain of international relations. As Jurgen Brauer shows, the relative absence of economics from international relations was not always the case: A range of exceedingly prominent past economists-from Adam Smith to John Maynard Keynes-routinely saw potential and actual conflict as an important economic concern. An edited collection of papers by Michelle Garfinkel and Stergios Skaperdas provides an indication of the contributions contemporary economists have made to the understanding of potential and actual interstate violent conflict, for instance through its links with trade and power, and its economic costs. In addition, however, their collection also makes clear that a major area of recent research has been the empirical analysis of the determinants of intrastate, or civil, war. So far, though, there has been relatively little overlap with the debates over the preparation for war (military spending and arms industry) discussed in the prior section. ${ }^{13}$

Research on intrastate conflict and war has been dominated by noneconomists. Initially, the generally accepted view was that violent conflict results from political grievances. Economists' involvement received a boost when the World Bank set up a Conflict and Development project. The focus moved to the material basis of violence, and cross-country research studies found that economic factors indeed were important in determining war onset, duration, and the probability of war recurrence. The resulting "greed versus grievance" debate was strong. Early statements of civil wars resulting from greed, with insurgents only as good as bandits, eventually led to more moderate research positions recognizing the likely importance of grievance while acknowledging the need for economic opportunities to exist before wars can occur. To be able to maintain conflict, insurgents do need some form of income, such as from lootable natural resources or overseas remittances. A burgeoning literature from both, politics and economics resulted. Much of the debate concerned the measurement of proxy variables used in the various studies and the expansion of the set of potential conflict-causing factors considered. Consensus findings suggest that economic factors are important in providing the opportunity for civil wars to arise, with natural resources of particular importance. Rather than greed or grievance, it is greed and grievance. This led to policies such as the Kimberley process to deal with the issue of "blood" diamonds whereby (mostly) Western consumers helped finance civil wars in faraway places. ${ }^{14}$

Focus on civil war stems, in part, from its (usually) asymmetric nature. Force structures and the security apparatus developed during the cold war and its immediate aftermath are no longer necessarily relevant. This does not mean that no work on other types of war have been done, but the civil war literature has tended to dominate in recent years. ${ }^{15}$

A somewhat less considered area regards the economic cost of war. This belies its importance both, in understanding the types of the negative impacts of those costs and also in policy to justify peacekeeping and peacemaking. The costs of prevention and intervention would seem to be dwarfed by the costs of war, particularly when spillover costs on neighboring countries or regions are considered. Paul Collier famously estimated that civil war leads to a GDP reduction of around two percent per war year, wiping out development gains in the affected economies. Although some think tank-based researchers consider the costs of conflict to be either overstated (Human Security Report) or understated (Institute for Economics and Peace), recent academic research estimates have not been inconsistent with Collier's findings. Either way, the costs of war are high and thus important in motivating continuing research both, on the cost of war and on the benefits of peace. As an indication, recent work has shown the health legacy effects of war to be pronounced and long lasting: Civil wars of twenty years ago still register an impact on a range of indicators today. Indeed, research points to even longer adverse effects in the case of genocides. Certainly, this literature allows strong economic arguments to be made for war prevention and post-war reconstruction and to make the case for economic policies aimed at preventing war recurrence. ${ }^{16}$

Another challenge concerns changes in the geopolitical environment and in the nature of conflict. As mentioned, some contributions are made by economists who, who account of some geopolitical event, unhelpfully "parachute" into a literature they are otherwise unfamiliar with. The changing nature of violent conflict also carries policy implications. For instance, the distinctions among civil war protagonists, transnational organized crime, and terror groups are becoming less clear, such as in the case of Boko Haram in Nigeria. Links 
to organized crime, for instance through human trafficking and the illicit narcotics trade, and to terror organizations exist across a number of such cases so that distinctions among crime, terror, and war become blurred. It is also plausible that some amount of violent conflict results from the continuous evolution of capitalism itself, giving rise to a potentially important area of research. ${ }^{17}$

\section{Post-war reconstruction and peace}

By far the main limitation of research has been the failure to develop what might be called a peace economics. The focus on conflict and war has gone in tandem with a relative paucity of work on post-war reconstruction as a major concern, leading to generic policy prescriptions, associated policy failures, and war recurrence. This is surprising, given that, as mentioned, peace economics was a major concern for economists in the past. In failing to attempt to understand the transition from war to peace, the default position has been to assume a blank slate and introduce generic structural adjustment and similar free market-oriented policies. The general failure of this approach is now widely recognized. Although more nuanced today, polices still are based on a partial understanding of the issues that arise in post-war security and economic environments. ${ }^{18}$

This suggests that more research is needed on the nature and inertial effects of war economies. This includes not merely the role that antagonists play in war but also the roles of civil society and the informal economy and of the legacies of violent conflict. As the case of Afghanistan shows, many policymakers have not heeded lessons from the experience of the past, creating a potentially important role for economists versed in peace and security, even as there are very few of them. Attempts are made to better understand the issues but many who work in the area are trained in orthodox economics which gives little thought to the development of policy in post-war environments. ${ }^{19}$

To develop a peace economics that provides guidance on how to create economies that are peaceful, and to keep them that way, means recognizing that all economic relations reflect the logic of an underlying structure and that each phase of postwar development can entail different challenges and opportunities. The first concerns just how fighting ends. Wars end in different ways - some end abruptly and some peter out - and it can take time to negotiate and put into practice any peace agreement which may or may not include provisions in regard to post-war economies. The end of different wars creates different dynamics and path-dependencies, meaning uniform post-war policies are unlikely to succeed. Second is rehabilitation and restoration. This will include the removal of limitations on civilian economic activity, reestablishing civilian law and institutions, disarming ex-combatants, demining roads, and returning displaced persons. Since economies differ prior to war, it is unlikely that a standard post-war package will suffice, nor is it always appropriate to return an economy to its pre-war state if, for instance, the pre-war economy was a major cause of war to begin with. Third comes reconstruction and/or replacement: This entails gaining financial resources for reconstruction, replacing and repairing physical capital and infrastructure, demobilization and resettlement, rehabilitating victims, introducing or reintroducing democratic structures, redeveloping and/or restructuring civilian institutions, and beginning societal reconciliation. While the tasks at hand are likely to be similar across cases so that reconstruction check lists can be useful, it is unlikely that the details will be similar. Fourth is development and transformation. Here the need lies in adopting and implementing a new vision, undertaking structural changes, establishing new institutions, and continuing reconciliation. ${ }^{20}$

Each stage presents its own challenges and carries different implications for international agencies that move in to support countries emerging from violence. It is also the case that state and nonstate agencies have their own interests and/or are restricted in how involved they can get and what contribution they can make, depending on structures and processes that already are in place. A war economy champions a logic that is very far from a peace economy. Vested interests that make money out of violence may not coincide with those that benefit from peace, so that moving away from conflict is difficult and peace accords are fraught with the possibility of warrecurrence. Indeed, peace is often declared even as violence continues under the guise of "peace." A striking example is given by the first "end" of the war in Colombia which did not lead to peace as commonly understood but led to further murders, drug-related violence, and the continued operation of the FARC. As Jurgen Brauer and J. Paul Dunne argue, to be serious about peace means creating structures that reflect the logic of peaceful relations, that make conflict unlikely, and that make peace irreversible. This means creating social contracts that embed peace through institutional design, by designing the necessary incentives, and determining the necessary roles of civil society. There will need to be recognition that processes of post-war development will go through stages that require changes in these incentives and structures. Major immediate concerns are policies for demobilization, reintegration, and reconciliation as the post-war processes take shape. ${ }^{21}$

In their book, Brauer and Dunne discuss principles for the design of contracts that do embed peace. Adhering to these principles will not guarantee peace but not adhering to them may well endanger it. Examples include changing payoffs to 
induce cooperative actions, creating vested interests and leadership in favor or peace, forming society-wide common values, creating an authentic governmental authority to make all segments of society feel that they participate in decisionmaking, establishing reasonably rapid, impartial, and effective conflict resolution mechanisms to deal with disputes as they occur, providing for independent avenues of information access, transparency, and monitoring to reduce uncertainty and misinformation and to hold leaders accountable. Certainly, a role exists for careful and considered external interventions to encourage peace and to support social and economic healing but "careful and considered" is not always what past experiences have been. ${ }^{22}$

Unsurprisingly, in any such research a major challenge concerns data. Given secrecy, issues of data availability, transparency, and quality arise, and these are considerably worse in countries affected by instability and war. Data reliability or accuracy are difficult to determine. Even conflict measures themselves leave a lot to be desired and, beyond that, much work remains to be done to improve measurement even if the measures were clear. Moreover, the very meaning of conflict and peace are not settled. As mentioned, war's end does not necessarily imply peace. Rather than to imply accuracy by using the number of battle deaths as a measure of war or peace for instance, in some cases it might be better to go with simple binary measures such as "conflict" and "no conflict." That said, the relatively recent development of geocoded and household-level data in war and post-war areas is providing valuable insights at disaggregated levels.

An important development has been the construction of the Global Peace Index (GPI) by the Institute for Economics and Peace. The intention was to move the focus away from what causes violent conflict to what causes peace and, with its high profile internationally, the Institute has had success. The GPI has been used in some empirical research but the index still suffers from a limited number of observations (10 years of data) and some index components are not replicable as they rely on opinion measures that cannot be extended backward in time. It also measures the absence of violence rather than the presence of peace. In contrast, the analogous construction of a Positive Peace Index (PPI), also by the Institute for Economics and Peace, is open to similar data critiques but at least tries to measure the conditions that make for peace in the future. ${ }^{23}$

Research on peacekeeping and its efficacy and efficiency is surprisingly limited. While the United Nations and other groupings such as the African Union have played important roles in maintaining peace in post-war environments, there also have been failures. Obviously, the prosecution of peace needs peacekeeping and peacemaking forces and related equipment, but the need is much different from what is made available. Developing the relevant forces and equipment could carry important implications for the nature and extent of the defense industrial base and its related vested interests. In addition, the development of international governance structures that operate considerably better than those at present will be required as well as the recognition of wider concepts of security. Following from the previous discussion, to develop successful policies and support for post-war reconstruction, a better understanding of the economics of violent conflict and war is needed, in part to make a better job of designing and maintaining peace accords and designing reconstruction packages that make the incentives for peace greater than those for a return to war. ${ }^{24}$

The cold war era saw considerable debate regarding the economic effect of reducing military expenditure and how to reconvert resources back to civilian use. Those who argued against military expenditure cuts in anticipation of significant economic problems faced, in fact, booming post-cold war economies in the 1990s. Of course, transition costs occur but these are no longer seen as significant. Swords to ploughshares is no longer considered sensible, but the macro, and meso, conversion policies of industrial restructuring are relevant. It is an interesting, if strange, debate to look back to and there are some useful analyses. Peace does not necessarily mean demilitarization and massively reduced military spending, but even if it did the evidence suggests that improved economic performance is possible if resources are moved from defense to civilian sectors of the economy. Resource shifts imply increased demand for civilian industry, stoking investment in plant upgrades and (alternative) technologies there. This can lead to knock-on effects such as policies to reduce inequalities, support sustainable development, and to improve the economic situation for all countries. Conversion also allows one's focus to transition from military to alternative concepts of security, such as human and environmental security, improving the situation of the population of developing countries in particular. Improved global trade - and the foreign exchange savings from not importing weapons systems - should reduce the likelihood of violent conflict as well, although the experience of this century thus far does make one wary of issuing such statements with confidence. Nevertheless, it is difficult to see anything but net economic benefits resulting from peace, and the peace and prosperity goal on which the United Nations is founded should be accepted by the vast majority of economists. The problem, in a word, is that the profession has become so focused on prosperity that it has overlooked peace as a necessary precondition. ${ }^{25}$ 


\section{Conclusion}

It should be easy to conclude from this review that economists have made important contributions to understanding causes, mechanisms, and consequences of the peace and security sectors. Although the subject area has grown in status as a field of research in economics, it remains a minority interest within the profession even as peace is a precondition for prosperity. And while we have gained a better understanding of the preparation for and the dynamics of conflict and war, the field nonetheless has failed to develop an understanding of how to embed peace in economic development - particularly in postwar reconstruction environments to help prevent war recurrence - and how to develop a peace economics separate from war, defense, conflict, or security economics.

Countries, even countries in conflict, can move toward a peace economy with defensive defense force structures. In addition, economists can make useful contributions as countries reconsider how best to create international governance structures aimed at the peaceful resolution of conflict and how to control the global flow of arms. Although some steps have been taken, these remain important challenges. This can complement the call from Patrick Regan to bring peace back into conflict studies, political science, and international relations, with a move to bring peace back into conflict and post-war economics. ${ }^{26}$

\section{Notes}

I am grateful to Jurgen Brauer, Efi Nikolaidou, and Ron Smith for comments. The usual disclaimer applies.

\section{Dunne and Coulomb (2008).}

2. Textbooks: For example, Thirwall's seventh edition (2003) had no discussion at all of conflict, war, and peace, and what has been added since then is insubstantial. Similarly, Todaro and Smith's eighth edition (2003) carried a section on military expenditure and development and more recently (twelfth edition, 2014) added a bit on the challenge of violent conflict, but again in a remarkably insubstantial way.

3. For example, Martin Feldstein (Harvard University professor, former chairman of the Council of Economic Advisers, former president of the American Economic Association, president emeritus of the National Bureau of Economic Research, and member of the President's Foreign Intelligence Advisory Board) argues for military Keynesianism without realizing this has been debated over many years and its simple arguments destroyed and discredited. See The Wall Street Journal (24 December 2008), "Defense Spending Would Be Great Stimulus." Robert Higgs provided a critical response on 2 January 2009 in "Military Keynesianism to the Rescue?" (http://www.independent.org/newsroom/article.asp?id=2399).
4. Historical standards: SIPRI Yearbook 2015, chapter 9. Four times the cost: See Dunne (2013a). Poorest countries: Collier (2007). Acemoglu and Robinson (2012) have resurrected an institutionalist perspective to growth and development economics that does allow for the importance of conflict and colonialism. Interestingly the authors are an economist and a political scientist.

5. Security environment and budget constraints: Smith (2009). Eisenhower: Eisenhower, a Republican, used his end of term speech in 1961 to warn of the dangers of the MIC. See https://www.youtube.com/watch?v=8y06NSBBRtY. Military solutions: Dunne, Perlo-Freeman, and Smith (2008).

6. Effects: d'Agostino, Dunne, and Pieroni (2012) review the approaches in the literature. Generally negative: Dunne and Tian (2013) showed that studies including cold war-era data were more likely to find adverse effects. Until 2016, studies were restricted to SIPRI data consistent back to 1988 only. Longer, backward-extended series have now become available. Dunne and Tian (2016b) and d'Agostino, Dunne, and Pieroni (2017) find that the backward extension still gives negative effects. Not good policy: See Dunne (2013b).

7. See Dunne and Sköns (2008; 2010).

8. Changing technologies: Dunne (2009); Dunne and Smith (2016). Transparency: See, e.g., Wulf (2005).

9. Justifications: See Brauer's reviews (2007a; 2007b) of Vernon Ruttan's 2006 book, Is War Necessary for Economic Growth? Military Procurement and Technology Development. For example, the technology underlying today's internet was a civilian research project before being taken over by a research arm of the U.S. Department of Defense. Also see the set of rather skeptical symposium papers, organized by Renaud Bellais, on innovation in the arms and military space industries in Europe, published in 2017 in The Economics of Peace and Security Journal (vol. 12, no.1). Conversion literature: See Dunne and Braddon (2008).

10. Myth: See Holden (2017).

11. Commissions and bribes: See Feinstein (2012). On offsets, see Brauer and Dunne (2004; 2011a).

12. Changing composition: Dunne, et al. (2007a; 2007b), Dunne and Smith (2016). Major challenge: As the industry further meshes with civilian industry, especially in regard to electronics, it could well become less visible and thus more difficult to control, nationally and internationally.

13. Major review: Morelli and Sonno (2017). Past economists: Brauer (2017). Economists' contribution: Garfinkel and Skaperdas (2012). Determinants of civil war: For an influential survey see Blattman and Miguel (2010).

14. Economic opportunities: See the debate sparked by Collier and Hoeffler (2004). Natural resources: See Sambanis (2002); Hoeffler (2012); Dunne and Tian (2017b). Kimberley process: Gold (2006). Also see Rigterink (2010) who considers the limitations of the methods used to measure the commercial flow of diamonds.

The Economics of Peace and Security Journal — ISSN 1749-852X — http://www.epsjournal.org.uk (C) EPS Publishing, 2017. All rights reserved. For permissions, email: ManagingEditor@epsjournal.org.uk 
15. Tended to dominate: As just one example of a non-civil war focus, see Polachek and Seiglie (2007).

16. Costs of violent conflict: Collier (1999); Smith (2014) provides a valuable overview of what has been achieved in the area. More recent estimates: See Dunne and Tian (2016a); HSR (2009/10); IEP (2016; 2017). Range of indicators: Dunne and Tian (2017a). Genocides: Soudis, Inklaar, and Maseland (2016).

17. Nigeria: Nwankpa (2015). Organized crime: Napoleoni (2007). Terror: Enders and Sandler (2012); Llusa and Tavares (2007). Capitalism: See Cramer (2006) for a perspective that warns that civil wars can be important for economic development, for example if they represent primitive accumulation.

18. Development of the peace economics field: For surveys, see, e.g., Coulomb (2004); Dunne and Coulomb (2008); and Brauer (2017). Failure of policies: See recent research reported in the World Bank's World Development Report 2011 and a chapter on Security and Governance in the World Development Report 2017. Related research concerns work on demobilization and reintegration strategies. See, e.g., http://www.un.org/en/peacekeeping/ [accessed 28 September 2017].

19. Afghanistan: See, e.g., Child (2014) and a set of symposium papers published in The Economics of Peace and Security Journal, Vol. 10, No. 2 (2015).

20. Underlying structure: Attempts have been made to understand economic conditions of lasting peace (e.g., Jha, 2007) and conditions needed for successful nonviolent social movements (Bhavnani and Jha, 2014). Phases of post-war development: Harris (1999).

21. Colombia: It is worth recalling Keynes' prescient book, The Economic Consequences of the Peace (1919) which, in analyzing the conditions that the Versailles Treaty imposed on post-war Germany, predicted the coming of a second world war. Logic of peaceful relations: Brauer and Dunne (2011b); Brauer and Dunne (2012); Smith and Tasiran (2012). Designing incentives: Anderton and Brauer (2016) argue in their collection that developing policies to prevent mass atrocities such as genocides will need to draw (at least) on behavioral economics and the economics of international and constitutional law which lie far outside the usual purview of conflict economists. Post-war development: Also see Murshed (2009) and the World Development Report 2011.

22. Brauer and Dunne: Brauer and Dunne (2012).

23. GPI: Also see PRIO data at http://grid.prio.org/\#/ and Households in Conflict Network http://www.hicn.org/. Extended backward: Huang and Throsby (2011).

24. Incentives for peace: On the economics of peacekeeping and peacemaking, see the articles in the symposium of papers in The Economics of Peace and Security Journal (Vol. 1, No. 2, 2006). Also see Bove (2011) and Sheehan (2011).
25. Conversion: See Brauer and Tepper Marlin (1992) for a U.S. study; Moller and Voronkov (1996) for various country studies; Gleditsch, et al. (1996) for an international study. Foreign exchange and national debt: Terhal (1982); Brzoska (1983); Dunne, Perlo-Freeman, and Soydan (2004).

26. Regan (2014).

\section{References}

Acemoglu, D. and J. Robinson. 2012. Why Nations Fail. New York: Crown.

Anderton, C.H. and J. Brauer, eds. 2016. Economic Aspects of Genocides, Other Mass Atrocities, and Their Prevention. New York: Oxford University Press.

https://doi.org/10.1093/acprof:oso/9780199378296.001.0001

Bhavnani, R. and S. Jha. 2014. "Gandhi's Gift: Lessons for Peaceful Reform from India's Struggle for Democracy." The Economics of Peace and Security Journal. Vol. 9, No. 1, pp. 76-88. https://doi.org/10.15355/epsj.9.1.76

Blattman, C. and E. Miguel. 2010. "Civil War." Journal of Economic Literature. Vol. 48, No. 1, pp. 3-57. https://doi.org/10.1257/jel.48.1.3

Bove, V. 2011. "A Theoretical Approach to the Demand and Supply for Peacekeeping." The Economics of Peace and Security Journal. Vol. 6, No. 2, pp. 26-33. https://doi.org/10.15355/epsj.6.2.26

Brauer, J. 2007a. "Vernon W. Ruttan. Is War Necessary for Economic Growth?" Economic Development and Cultural Change. Vol. 55, No. 3, pp. 627-631 [substantively different from the item below]. https://doi.org/10.1086/511288

Brauer, J. 2007b. "Review Article: Is War Necessary for Economic Growth?" The Economics of Peace and Security Journal. Vol. 2, No. 1, pp. 71-76 [substantively different from the item above]. https://doi.org/10.15355/2.1.71

Brauer, J. 2017. "'On the Expence of Defence': What Have We Learned Since Adam Smith?" Peace Economics, Peace Science, and Public Policy. Vol. 23, No. 2, Art. 1. https://doi.org/10.1515/peps-2017-0012

Brauer, J. and J.P. Dunne, eds. 2004. Arms Trade and Economic Development: Theory, Policy, and Cases in Arms Trade Offsets. London: Routledge. https://doi.org/10.4324/9780203392300

Brauer, J. and J.P. Dunne. 2011a. "Arms Trade Offsets: What Do We Know?” pp. 243-265 in C.J. Coyne and R.L. Mathers, eds. Handbook on the Political Economy of War. Cheltenham, UK: Elgar. https://doi.org/10.4337/9781849808323.00022

Brauer, J. and J.P. Dunne. 2011b. "Macroeconomics and Violence," pp. 311-337 in D. Braddon and K. Hartley, eds. Handbook on the Economics of Conflict. Cheltenham, UK: Elgar. https://doi.org/10.4337/9780857930347.00018

Brauer, J. and J.P. Dunne. 2012. Peace Economics: A Macroeconomic Primer for Violence-Afflicted States.

The Economics of Peace and Security Journal — ISSN 1749-852X — http://www.epsjournal.org.uk (C) EPS Publishing, 2017. All rights reserved. For permissions, email: ManagingEditor@epsjournal.org.uk 
Washington, D.C.: United States Institute of Peace Press.

Brauer, J. and J. Tepper Marlin. 1992. "Converting Resources from Military to Non-Military Uses." Journal of Economic Perspectives. Vol. 6, No. 4, pp. 145-164.

https://doi.org/10.1257/jep.6.4.145

Brzoska, M. 1983. "Research Communication: The Military Related External Debt of Third World Countries." Journal of Peace Research. Vol. 20, No. 3, pp. 271-277. https://doi.org/10.1177/002234338302000308

Child, T.B. 2014. "Hearts and Minds Cannot Be Bought: Ineffective Reconstruction in Afghanistan." The Economics of Peace and Security Journal. Vol. 9, No. 2, pp. 43-49. https://doi.org/10.15355/epsj.9.2.43

Collier, P. 1999. "On the Economic Consequences of Civil War." Oxford Economic Papers. Vol. 51, No. 1, pp. $168-183$. https://doi.org/10.1093/oep/51.1.168

Collier, P. 2007. The Bottom Billion: Why the Poorest Countries are Failing and What Can Be Done About It. Oxford, UK: Oxford University Press.

Collier, P. and A. Hoeffler. 2004. "Greed and Grievance in Civil War." Oxford Economic Papers. Vol. 56, No. 4, pp. 563-595.

https://doi.org/10.1093/oep/gpf064

Coulomb, F. 2004. Economic Theories of Peace and War. London: Routledge. https://doi.org/10.4324/9780203495964

Cramer, C. 2006. Civil War is Not a Stupid Thing: Accounting for Violence in Developing Countries. London: Hurst \& Co.

D’Agostino, G., J.P. Dunne, and L. Pieroni. 2012. “Assessing the Effects of Military Expenditures on Economic Growth," pp. 388-411 in S. Skaperdas and M. Garfinkel, eds. Oxford Handbook of the Economics of Peace and Conflict. New York: Oxford University Press.

D’Agostino, G., J.P. Dunne, and L. Pieroni. 2017. "Does Military Spending Matter for Long Run Growth?” Defence and Peace Economics. Vol. 28, No. 4, pp. 429-436. https://doi.org/10.1080/10242694.2017.1324723

Dunne, J.P. 2009. "Developments in the Global Arms Industry from the End of the Cold War to the Mid-2000s," pp. 13-37 in R. Bitzinger, ed. The Modern Defense Industry: Political, Economic and Technological Issues. Westport, CT: Praeger.

Dunne, J.P. 2013a. "Armed Conflicts,", pp. 21-53 in B. Lomborg, ed. Global Problems, Smart Solutions: Costs and Benefits. Cambridge, UK: Cambridge University Press. https://doi.org/10.1017/CBO9781139600484.003

Dunne, J.P. 2013b. "Military Keynesianism," pp. 117-129 in Li Junsheng, Chen Bo and Hou Na, eds. Cooperation for a Peaceful and Sustainable World. Emerald: Bingley, UK.

Dunne, J.P. and D. Braddon. 2008. "Economic Impact of Military R\&D." Report. Brussels: Flemish Peace Institute.

Dunne, J.P. and F. Coloumb. 2008. "Peace, War, and International Security: Economic Theories," pp. 13-36 in J. Fontanel and M. Chatterji, eds. War Peace and Security.
Bingley, UK: Emerald. https://doi.org/10.1016/S1572-8323(08)06002-5

Dunne, J.P., M. Garcia-Alonso, P. Levine, and R.P. Smith. 2007a. "Determining the Defence Industrial Base." Defence and Peace Economics. Vol. 18, No. 3, pp. 199-221. https://doi.org/10.1080/10242690600924273

Dunne, J.P, M. Garcia-Alonso, P. Levine, and R.P. Smith. 2007b. "The Evolution of the International Arms Industries," pp. 97-120 in Wolfram Elsner, ed. Arms, War, and Terrorism in the Global Economy Today: Economic Analyses and Civilian Alternatives. Transaction Publishers: New Brunswick, NJ, and Zurich: LIT Verlag.

Dunne, J.P., S. Perlo-Freeman, and A. Soydan, 2004. "Military Expenditure and Debt in Small Industrialised Economies: A Panel Analysis." Defence and Peace Economics. Vol. 15, No. 2, pp. 125-132. https://doi.org/10.1080/1024269032000110504

Dunne, J.P., S. Perlo-Freeman, and R.P. Smith. 2008. "The Demand for Military Spending: Hostility versus Capability." Defence and Peace Economics. Vol. 19, No. 2, pp 293-302. https://doi.org/10.1080/10242690802166566

Dunne, J.P. and E. Sköns 2008. “Arms Production, Economics of," pp. 112-114 in L. Kurtz, ed. Encyclopaedia of Violence, Peace and Conflict. 2nd ed. Amsterdam: Elsevier.

Dunne, J.P. and E. Sköns. 2010. "Military Industrial Complex," pp. 281-292 in A. Tan, ed. The Global Arms Trade: A Handbook. London: Europa/Routledge.

Dunne, J.P. and R.P. Smith. 2016. "The Evolution of Concentration in the Arms Market." The Economics of Peace and Security Journal. Vol. 11, No. 1, pp. 12-17. https://doi.org/10.15355/epsj.11.1.12

Dunne, J.P and N. Tian. 2013. "Military Spending and Growth: A Survey." The Economics of Peace and Security Journal. Vol. 8, No. 1, pp. 5-11. https://doi.org/10.15355/epsj.8.1.5

Dunne, J.P. and N. Tian. 2016a. "Costs of Civil War and Fragile States." African Economic Research Consortium Working Paper http://www.aercafrica.org/images/ announcements/Costs\%20of\%20Civil\%20War\%20and $\% 20$ Fragile $\% 20$ States.pdf.

Dunne, J.P. and N. Tian. 2016b. "Military Expenditure and Economic Growth, 1960-2014." The Economics of Peace and Security Journal. Vol. 11, No. 2, pp. 50-56. https://doi.org/10.15355/epsj.11.2.50

Dunne, J.P. and N. Tian. 2017a. "Legacies of Civil Wars: The Long Term Health Costs After the Fighting Ends." Centre for the Study of African Economies, Conference, Oxford University, March 2017. Available at https:/editorialexpress.com/cgi-bin/conference/download .cgi?db_name $=$ CSAE2017\&paper $i d=632$.

Dunne, J.P. and N. Tian. 2017b. "Conflict and Fragile States in Africa." African Development Bank Working Paper 274. https://www.afdb.org/fileadmin/uploads/afdb/Documents 
/Publications/WPS_No_274_Conflict_and_Fragile_Stat es in Africa.pdf.

Enders, $\overline{\mathrm{W}}$. and T. Sandler. 2012. The Political Economy of Terrorism. 2nd edition. New York: Cambridge University Press.

Feinstein, A. 2012. The Shadow World: Inside the Global Arms Trade. New York: Penguin.

Garfinkel, M.R. and S. Skaperdas, eds. 2012. Oxford Handbook of the Economics of Peace and Conflict. New York: Oxford University Press. https://doi.org/10.1093/oxfordhb/9780195392777.001.0001

Gleditsch, N.P., A. Cappelen, O. Bjerkholt, R.P. Smith, and J.P. Dunne, eds. 1996. The Peace Dividend. Amsterdam: North Holland. https://doi.org/10.1108/S0573-8555(1996)235

Gold, D. 2006. "The Attempt to Regulate Conflict Diamonds." The Economics of Peace and Security Journal. Vol. 1, No. 1, pp. 49-52. https://doi.org/10.15355/epsj.1.1.49

Harris, G. 1999. Recovery from Armed Conflict in Developing Countries. London: Routledge.

Hoeffler, A. 2012. “On the Causes of Civil War,” pp. 179-204 in M.R. Garfinkel and S. Skaperdas, eds. Oxford Handbook of the Economics of Peace and Conflict. New York: Oxford University Press. https://doi.org/10.1093/oxfordhb/9780195392777.013.0009

Holden, P. 2017. Indefensible: Seven Myths that Sustain the Global Arms Trade. London: Zed Books and Chicago, IL: The University of Chicago Press.

[HSR] Human Security Report. 2009/10. "The Causes of Peace and the Shrinking Costs of War." Human Security Report Project and Oxford University Press.

Huang, S. and D. Throsby. 2011. "Economic, Political, and Social Determinants of Peace." The Economics of Peace and Security Journal. Vol. 6, No. 2, pp. 5-14. https://doi.org/10.15355/epsj.6.2.5

[IEP] Institute for Economics and Peace. 2016. "Positive Peace Report." Sydney: Institute for Economics and Peace.

[IEP] Institute for Economics and Peace. 2017. "Global Peace Index 2017." Sydney: Institute for Economics and Peace.

Jha, S. 2007. "Maintaining Peace Across Ethnic Lines: New Lessons from the Past." The Economics of Peace and Security Journal. Vol. 2, No. 2, pp. 89-93. https://doi.org/10.15355/epsj.2.2.89

Llusa, F. and J. Tavares. 2007. "The Economics of Terrorism: A Synopsis." The Economics of Peace and Security Journal. Vol. 2, No. 1, pp. 62-70. https://doi.org/10.15355/2.1.62

Moller, B. and L. Voronkov, eds. 1996. Defense Doctrines and Conversion. Aldershot, UK: Dartmouth.

Morrelli, M. and T. Sonno. 2017. "On Economic Interdependence and War." Journal of Economic Literature. Vol. 55, No. 3, pp. 1084-1097. https://doi.org/10.1257/jel.20161353

Murshed, M.S. 2009. "Conflict as the Absence of Contract." The Economics of Peace and Security Journal. Vol. 4, No.
1, pp. 32-38.

https://doi.org/10.15355/epsj.4.1.32

Napoleoni, L. 2007. "Terrorist Financing Beyond 9/11." The Economics of Peace and Security Journal. Vol. 2, No. 1, pp. 41-44.

https://doi.org/10.15355/2.1.41

Nwankpa, M. 2015. “The Political Economy of Securitization: The Case of Boko Haram, Nigeria." The Economics of Peace and Security Journal. Vol. 10, No. 1, pp. 32-39. https://doi.org/10.15355/epsj.10.1.32

Polachek, S. and C. Seiglie 2007. "Trade, Peace and Democracy: An Analysis of Dyadic Disputes," pp. 1020-1073 in T. Sandler and K. Hartley, eds. Handbook of Defense Economics. Vol. 2. Amsterdam: Elsevier.

Regan, Patrick M. "Bringing Peace Back In: Presidential Address to the Peace Science Society, 2013." Conflict Management and Peace Science. Vol. 31, No. 4, pp. 345-356.

https://doi.org/10.1177/0738894214530852

Rigterink, A.S. 2010. "Natural Resources and Civil Conflict: An Overview of Controversies, Consensus, and Channels." The Economics of Peace and Security Journal. Vol. 5, No. 2, pp. 17-22. https://doi.org/10.15355/epsj.5.2.17

Ruttan, V.W. 2006. Is War Necessary for Economic Growth? Military Procurement and Technology Development. New York: Oxford University Press.

https://doi.org/10.1093/0195188047.001.0001

Sambanis, N. 2002. "A Review of Recent Advances and Future Directions in the Quantitative Literature on Civil War." Defence and Peace Economics. Vol. 13, No. 3, 215-243. https://doi.org/10.1080/10242690210976

[SIPRI] Stockholm International Peace Research Institute. Various years. SIPRI Yearbook. Oxford, UK: Oxford University Press.

Sheehan, N. 2011. The Economics of UN Peacekeeping. London: Routledge.

Smith, R.P. 2014. "The Economic Costs of Military Conflict." Journal of Peace Research. Vol. 51, No. 2, pp. 245-256. https://doi.org/10.1177/0022343313496595

Smith, R.P. 2009. Military Economics. London: Palgrave. https://doi.org/10.1057/9780230244672

Smith, R.P. and A. Tasiran. 2012. "The Onset of Peace." The Economics of Peace and Security Journal. Vol. 7, No. 1, pp. 5-14. https://doi.org/10.15355/epsj.7.1.5

Soudis, D., R. Inklaar, and R. Maseland. 2016. "The Macroeconomic Toll of Genocide and the Sources of Economic Development," pp. 125-139 in C.H. Anderton and J. Brauer, eds. Economic Aspects of Genocides, Other Mass Atrocities, and Their Prevention. New York: Oxford University Press. https://doi.org/10.1093/acprof:oso/9780199378296.003.0005

Terhal, P. 1982. "Foreign Exchange Costs of the Indian Military, 1950-1972.” Journal of Peace Research. Vol. 19, 
No. 3, pp. 251-259.

https://doi.org/10.1177/002234338201900304

Thirwall, A. 2003. Growth and Development. 7th edition. Basingstoke, UK: Palgrave Macmillan.

Todaro, M.P. and S. Smith. 2003. Economic Development. 8th edition. Harlow, UK: Pearson Education Ltd.

Wulf, H. 2005. Internationalizing and Privatizing War and Peace. Basingstoke, UK: Palgrave.

https://doi.org/10.1057/9780230514812 